Ar-Risalah: Media Keislaman, Pendidikan dan Hukum Islam

Volume XVIII Nomor 1 Tahun 2020

Print ISSN : 1693-0576

Online ISSN : 2540-7783

\title{
PELUANG DAN TANTANGAN PENDIDIKAN MUHAMMADIYAH DI ERA 4.0
}

\author{
Umar Al Faruq \\ Universitas Islam Negeri (UIN) Maulana Malik Ibrahim Malang, Indonesia \\ Program Doktoral Pasca Sarjana Universitas Muhammadiyah Malang, Indonesia \\ e-mail: mazalfa2018@gmail.com
}

\begin{abstract}
This research article discusses the opportunities and challenges of Muhammadiyah education in the 4.0 Era. In this research researchers used a qualitative approach with the type of research libraries. The sources used are research journals, articles, books and other related information that can support data from this research. The results of the study are Muhammadiyah education has many chances to be able to compete because 1. It carries Tajdid movement or renewal, 2. In the direction of Indonesia and UUD 1945, 3. Relevant to the demands of the times, 4. It has a strong network both nationally and internationally. The strongest challenge faced by Muhammadiyah is the technology that is the fundamental core of the changes in the disruption era in the 4.0 industry.
\end{abstract}

Keywords: opportunities and challenges, Muhammadiyah education, 4.0 era

\begin{tabular}{|c|c|c|}
\hline Accepted: & Reviewed: & Publised: \\
Maret 092020 & Maret 25 2020 & April 30 2020 \\
\hline
\end{tabular}

\section{A. Pendahuluan}

Kemajuan ilmu pengetahuan dan teknologi menuntut semua pihak untuk dapat berkompetensi agar tidak tergerus dan terlindas oleh zaman. Digitalisasi di seluruh belahan dunia memaksa kita untuk ikut andil dan ambil peran di dalamnya jika tidak ingin mengalami ketertinggalan. Era industri 4.0 telah menghadirkan fenomena disrupsi pada berbagai sendi kehidupan. Peran manusia akan mulai tergantikan dengan teknologi digital. Segala kemajuan yang ada membawa dampak posistif dan negatif bagi kehidupan kita, tergantung bagaimana kita menyikapinya. Berbagai bentuk kemajuan pengetahuan dan teknologi telah dirasakan bersama. Pada satu sisi, kemajuan ini dirasakan membawa perubahan yang lebih baik, memberian kemudahan manusia dalam berbagai kebutuhan dan pekerjaan. Tapi, pada sisi yang lain justru menimbulkan permasalahan tersendiri bagi umat. Perubahan yang ada terjadi pada berbagai lini dan sendi kehidupan, di antaranya pola hidup keagamaan, pendidikan, kesehatan, politik dan bisnis.

This work is licensed under Creative Commons Attribution Non Commercial 4.0 International License Available online on: http://ejournal.iaiibrahimy.ac.id/index.php/arrisalah/index 
Era 4.0 menuntut semua pihak untuk berpikir progresif, inovatif, dan kreatif jika tidak ingin ketinggalan langkah. Era ini menuntut banyak perubahan di berbagai lini kehidupan. Era industri 4.0 yang dikenal dengan fenomena disruptive innovation ini menekankan pola digital economy, artificial intelligence, big data, robotic dan lain sebagainya. Menghadapi tuntutan yang luar biasa ini, lembaga pendidikan menghadapi tantangan berat untuk menghadirkan pendidikan yang berkualitas dan menghasilkan lulusan profesional yang handal dan mampu bersaing di masa depan.

Pendidikan di era 4.0 menekankan pada pemanfaatan teknologi digital dalam proses pembelajaran yang berlangsung. Cyber system ini tentu membawa perubahan besar bagi proses pembelajaran yang ada. Pembelajaran yang berlangsung menjadi lebih mudah, cepat dan berkelanjutan. Pembelajaran tidak lagi tersekat dan terbatas oleh ruang dan waktu. Proses pembelajaran dapat berjalan dan berlangsung di manapun dan kapanpun saja. Seorang siswa tidak harus bertatap muka secara langsung dengan gurunya saat proses transformasi ilmu pengetahuan. Tentu di samping kemudahan yang dibawa dan ditawarkan oleh adanya kemajuan teknologi digital ini, dalam sisi yang lain akan memberikan tantangan tersendiri bagi lembaga-lembaga pendidikan, terutama lembaga pendidikan yang masih terkesan gagap teknologi (gaptek) atau belum siap dengan adanya kemajuan ini.

Kuantitas lembaga pendidikan di Indonesia mengalami dinamika yang luar biasa. Di berbagai tempat menjamur lembaga-lembaga pendidikan dengan berbagai orientasi. Persaingan antar lembaga pendidikan dalam mengelolah sistem pendidikan yang dimiliki semakin gencar dilakukan. Disisi lain, pemerintah berusaha untuk terus mengevaluasi berbagai problematika pendidikan yang ditemukan di lapangan. Baru-baru ini, pemerintah khususnya kementerian pendidikan disibukkan dengan rencana perubahan kurikulum pendidikan yang ada. Kurikulum pendidikan yang diterapkan saat ini dinilai kurang efektif dan menjadi beban berat bagi anak didik di sekolah. Kurikulum di sekolah dinilai kurang efektif dan kurang implementatif bagi kehidupan anak didik. Pendidikan menjadi kurang terarah dikarenakan muatan matapelajaran yang terlalu banyak dan tidak fokus pada kompetensi yang dimiliki oleh peserta didik.

Kehadiran era 4.0 yang ditandai dengan digitalisasi dalam berbagai lini akan menghadirkan sebuah kemajuan atau progresivitas. Berbagai kemajuan yang ada sengaja dibuat dengan tujuan untuk membawa perubahan yang lebih baik. Maka seharusnya dengan kemajuan ilmu pengetahuan dan teknologi tersebut, kehidupan umat manusia menjadi lebih baik, lebih maju dan beradab. Akan tetapi, pada kenyataannya tidak sedikit pula dampak kemajuan yang ada justru menimbulkan 
permasalahan tersendiri. Berbagai problematika dan ketimpangan yang disebabkan adanya kemajuan tersebut banyak sekali terjadi di lapangan.

Semua kemajuan ilmu pengetahuan dan teknologi yang ada merupakan hasil dari pendidikan yang dijalankan. Pendidikan yang baik akan menghasilkan karya, kemajuan dan membawa progresivitas yang cemerlang untuk suatu bangsa dan umat. Oleh sebab itu, seharusnya pendidikan menjadi suatu hal yang esensial bagi setiap bangsa demi kemakmuran rakyat yang ada di dalamnya. Dalam menyikapi hal ini, banyak lembaga pendidikan dan organisasi yang berusaha untuk menciptakan dan terjun langsung ke dalam ranah pendidikan. Salah satu dari organisasi yang turut andil mengambil bagian untuk bergerak di bidang pendidikan adalah Muhammadiyah.

Muhammadiyah adalah organisasi Islam yang banyak menaruh perhatian pada bidang dakwah, pendidikan, kesehatan dan amal usaha lainnya, juga dalam hal politik. Muhammadiyah dikenal sebagai gerakan tajdid, reformis, progresif pada berbagai lini termasuk lini pendidikan. Sebagai gerakan tajdid, gerakan reformis, gerakan pembaharuan yang berkemajuan sudah seharusnya Muhammadiyah perperan aktif dalam menanggulangi dan mencari solusi dari berbagai problematika sosial yang ada. Kader Muhammadiyah yang dikenal kritis sudah sepatutnya tidak berdiam diri menyikapi berbagai persoalan yang dihadapi umat. Muhammadiyah harus berani menciptakan peluang-peluang bagi umat dalam menghadapi segala bentuk persaingan yang ada. Muhammadiyah harus berani menjawab berbagai tantangan yang menghadang di depan. Dengan pengalamannya sebagai organisasi Islam yang sudah berdiri sejak tahun 1912 M, Muhammadiyah dirasa sudah sangat berpengalaman makan manis dan pahitnya perjuangan hidup. Muhammadiyah harus menjadi problem solver terhadap masalah yang ada, minimal memberikan kontribusi nyata dengan berbagai ide cemerlang dan aksi kongkrit, solutif terhadap berbagai persoalan yang ada.

Pendidikan merupakan salah satu pilar penting suatu bangsa selain ekonomi dan keamanan. Pendidikan menjadi salah satu tolak ukur sumber daya manusia yang dimiliki atau yang ada pada satu bangsa tertentu. Maka artinya, pendidikan memiliki peran yang penting untuk kemajuan suatu bangsa. Oleh sebab itu, perhatian terhadap pendidikan tidak boleh dikesampingkan bahkan harus menjadi prioritas utama untuk mencetak dan melahirkan insan-insan akademis yang akan menjadi tonggak bagi kemajuan bangsa. Bangsa yang penduduknya berpendidikan tinggi dan maju, akan menjadikan bangsa tersebut maju dan disegani oleh bangsa lainnya.

Muhammadiyah adalah satu organisasi Islam besar di Indonesia yang menaruh perhatian besar terhadap pendidikan. Rekam jejak Muhammadiyah dalam 
berkontribusi di dunia pendidikan memiliki sejarah yang sangat panjang. Sebelum Indonesia merdeka, Muhammadiyah telah bergelut dan berkecimpung dengan dunia pendidikan sejak zaman kolonial Belanda. Sistem pendidikan yang diselenggarakan oleh kolonial Belanda hanya menguntungkan para penjajah saja. Masyarakat pribumi tidak pernah merasakan hasil dari pendidikan tersebut. Oleh sebab itu, pada saat itulah KH. Ahmad Dahlan yang merupakan pendiri organisasi Muhammadiyah mulai berfikir untuk mengentaskan pribumi dari segala bentuk kebodohan yang diterapkan oleh kolonial Belanda. Berbagai problematika dihadapi oleh masyarakat Indonesia saat itu, maka Muhammadiyah lahir sebagai jawaban dan solusi atas berbagai problematika yang ada di masyarakat di antaranya bidang agama, sosial dan pendidikan.

Langkah Muhammadiyah tidak pernah surut untuk berperan memajukan pendidikan di bangsa ini. Perjuangan Muhammadiyah dalam dunia pendidikan sudah terlihat dengan jelas dan hasilnya pun dapat dinikmati bersama. Bukti sejarah Muhammadiyah dapat dilihat dengan menjamurnya lembaga-lembaga pendidikan yang beraviliasi ke Muhammadiyah. Mulai dari tingkat taman kanak-kanak yang dikenal dengan TK Aisyiah, sampai pada perguruan tinggi Muhammadiyah. Bahkan saat ini Muhammadiyah sedang ber-fastabiqul khoirot dengan sesama organisasi Muhammadiyah yaitu Aisyiah, organisasi Muhammadiyah yang mewakili kaum hawa dalam memajukan pendidikan bangsa. Sehingga saat ini, dapat kita lihat mulai bermunculan lembaga-lembaga pendidikan dengan nama Aisyiah.

Muhammadiyah adalah organisasi dakwah amar ma'ruf nahi mungkar yang andil besar dalam bidang pendidikan yang ada di Indonesia. Muhammadiyah memiliki keterkaitan yang unik dan spesial dengan dunia pendidikan. Manifestasi gerakan Muhammadiyah dalam bidang pendidikan adalah yang paling menonjol dan mengakar (Ali, 2016). Muhammadiyah adalah organisasi Islam dan kemasyarakatan, organisasi dakwah yang menaruh perhatian besar pada dunia pendidikan. Bahkan saat ini Muhammadiyah menjadi organisasi yang berpengaruh dalam dunia pendidikan. Dengan gerakan tajdidnya Muhammadiyah mampu berkembang dengan baik seiring kemajuan zaman sehingga mudah diterima oleh seluruh elemen masyarakat Indonesia bahkan dunia. Kemajuan organisasi ini tak lepas dari visi-misi, konsep pendidikan, tujuan, maupun kurikulum yang saling berkesinambungan sehingga Muhammadiyah dapat berproses dengan baik dalam masyarakat (Rusydi, 2017).

Dengan pengalaman yang sudah lama dimilikinya, seharusnya Muhammadiyah mampu menghadirkan sebuah sistem pendidikan yang maju, yang dapat menjadi contoh bagi lembaga pendidikan lainnya. Muhammadiyah hendaknya bisa memberikan harapan bagi bangsa terkait sistem pendidikan yang ada, karena 
Muhammadiyah dianggap organisasi yang sudah lama terjun ke dalam dunia pendidikan. Dalam langkah gerak Pendidikan Muhammadiyah tidak lepas dari berbagai kritikan, bahkan kritikan yang ada justru memposisikan pendidikan di Muhammadiyah masih dianggap belum mampu menghadirkan sistem pendidikan yang diharapkan bersama. Bahkan kritik keras seringkali dilontarkan oleh Prof. M. Yunan Yusuf, Ketua Majlis Pendidikan Dasar dan Menengah (Dikdasmen) Muhammadiyah Pusat periode 2000-2005, tentang wacana robohnya sekolah Muhammadiyah sebagai bentuk gambaran dari rendahnya kualitas dan mutu pendidikan atau sekolah yang ada di Muhammadiyah. Kritikan yang lain juga datang karena melihat cerminan tingkah laku warga sekolah yang masih belum mencerminkan nilai-nilai Islam, sekolah Muhammadiyah belum mampu menciptakan kultur Islami, bahkan cenderung kehilangan identitasnya dan dianggap lebih kooperatif dengan kelompok penekan (Ali \& Ali, 2004). Selain itu, Muhammadiyah dinilai masih bertahan dengan tradisinya yang lama dalam penyelenggaraan pendidikan sehingga terkesan tertinggal dengan sitem pendidikan lainnya yang mulai beradaptasi dengan kemajuan zaman. Era kemajuan teknologi dapat menggerus berbagai rangkaian sistem pendidikan lama karena ketertinggalannya di era digital. Maka untuk keluar dari kondisi yang tertinggal ini, sudah seharusnya bagi Muhammadiyah untuk merubah sistem pendidikan yang ada, atau membuat inovasi-inovasi terkait pendidikan agar tidak tertinggal oleh lainnya.

Bertolak dari latar belakang diatas, maka perlu kiranya untuk mengkaji dan meneliti bagaimana pendidikan yang ada dalam Muhammadiyah berikut dengan peluang yang dimilikinya serta tantangan yang dihadapinya. Oleh sebab itu, artikel ini akan membahas tentang peluang dan tantanga pendidikan Muhammadiyah di era 4.0.

\section{B. Metode Penelitian}

Penelitian ini menggunakan pendekatan kualitatif. Jenis penelitian ini adalah studi pustaka. Peneliti berusaha menelaah informasi dan pengetahuan dari berbagai literatur dan referensi yang ada. Semua sumber data diperoleh dari berbagai sumber seperti jurnal ilmiah, buku, artikel di internet yang mendukung serta bacaan lain yang mampu memberikan informasi untuk menguatkan data yang ada. 


\section{Hasil dan Pembahasan}

\section{Pendidikan Muhammadiyah}

Pendidikan adalah sebuah usaha membentuk warga Negara menjadi good netizen untuk dapat menjalankan peranannya di negaranya (Wuryandani et al., 2016). Perkembangan pendidikan di Muhammadiyah ini tak lepas daripada pendirinya yang merupakan tokoh bangsa, pahlawan nasional yang dengan segala keikhlasan, pengorbanan dan dedikasinya berkorban tenaga, pikiran, harta, waktu dan lain sebagainya untuk perjuangan umat. Berusaha melepaskan umat dari penindasan dan kebodohan yang menimpa bangsa Indonesia. Penindasan yang dilakukan oleh kolonial Belanda, membuat KH. Ahmad Dahlan selaku pendiri Muhammadiyah berfikir kritis dan cerdas bagaimana menjadikan setiap kesempatan yang ada untuk menyelamatkan umat dari segala bentuk penindasan yaitu kebodohan.

Poerbakawatja, seorang pengkaji sejarah mengatakan ada tiga tokoh pendidikan pribumi sebagai perintis pendidikan modern di perguliran abad ke-20. KH. Ahmad Dahlan melalui pergerakan Muhammadiyah yang berdiri pada 18 November 1912. Ki Hajar Dewantara pendiri Taman Siswa pada tahun 1922. Muhammad Sjafei pendiri Ruang Pendidikan INS Kayutanam di Sumatera Barat pada tahun 1926 (Ali et al., 2016). Ketiganya merupakan tokoh bangsa yang memiliki kecerdasan, semangat, kegigihan. Mereka berinisiatif meramu senjata pamungkas yang mereka pinjam dari kolonial Belanda sehingga lebih sesuai dengan kebutuhan penduduk pribumi.

Muhammadiyah diakui memang menaruh perhatian besar pada pendidikan. Dalam pandangan umum, Muhammadiyah juga telah berusaha untuk dapat bersaing dengan lembaga pendidikan maju lainnya baik yang bersifat lokal, nasional maupun internasional. Berbagai lompatan telah dilakukan oleh Muhammadiyah untuk memajukan pendidikan yang ada di Indonesia. Semuanya dilakukan dengan tujuan dalam rangka peningkatan sumber daya manusia yang berkemajuan. Rancangan sistem pendidikan Islam modern Muhammadiyah sejak awal adalah memadukan antara ilmu-ilmu agama dengan ilmu umum serta intergrasi trilogi pembangunan yaitu pendidikan keluarga, sekolah dan masyarakat. Inilah konsep pendidikan Muhammadiyah yang sejak dulu telah digagas oleh pendiri organisasi ini yaitu $\mathrm{KH}$. Ahmad Dahlan. Beliau yang merupakan seorang visioner telah melahirkan ide-ide dan gagasan cemerlang yang mampu memproyeksikan pendidikan ke depan sehingga melahirkan sebuah pendidikan modern yang berkesinambungan antara ilmu agama dan ilmu umum.

Sistem pendidikan yang dimiliki oleh Muhammadiyah sekarang ini hendaknya dapat terus dikembangkan dan diperbaiki dengan mengikuti perkembangan zaman 
yang ada. Era digital dan disrupsi menuntut kita untuk memacu langkah kita lebih cepat agar tidak tertinggal oleh zaman. Muhammadiyah harus mampu menjawab setiap tantangan yang ada di depan, khususnya di era disrupsi di mana setiap kegiatan yang normal dilakukan oleh manusia akan berubah tergantikan oleh teknologi yang ada. Muhammadiyah juga harus mampu memberikan peluang kepada generasi pelajar agar mereka memiliki harapan dan memiliki lembaga yang mampu memberikan mereka pendidikan yang baik untuk mampu bersaing dengan lembaga pendidikan lainnya.

Sebagai sebuah organisasi kemasyarakatan, Muhammadiyah menjadikan pendidikan sebagai area of concern dan terlibat dalam "eksperimen pendidikan Islam modern" pada awal abad ke 20 (Listiana, 2015). Muhammadiyah melakukan modernisasi pendidikan serta menjadikannya sebagai agenda utama untuk memperbaiki kualitas pendidikan yang ada di Indonesia. Muhammadiyah dianggap sebagai trendsetter dan mesin lokomotif terhadap gerakan reformasi pendidikan yang ada. Tujuan pendidikan Muhammadiyah tidak terlepas dari apa yang dicanangkan oleh pendirinya KH. Ahmad Dahlan yaitu mencetak seorang ulama yang berkemajuan dalam ilmu pengetahuan, serta tidak kenal lelah dalam memperjuangkan dan berjuang di Muhammadiyah.

Tujuan pendidikan yang dicanangkan oleh KH. Ahmad Dahlan ini selanjutnya menginspirasi bagi organisasi Muhammadiyah bahwa pendidikan Muhammadiyah harus mampu melahirkan seorang yang memiliki ilmu pengetahuan agama dan ilmu pengetahuan umum secara luas dan mendalam secara berimbang (balance) (Arofah \& Jamu'in, 2015). Di samping itu juga harus memiliki loyalitas tanpa batas untuk berjuang dalam organisasi Muhammadiyah. Hal ini juga sesuai dengan pesan Ahmad Dahlan "Hidup hidupilah Muhammadiyah, jangan mencari kehidupan di Muhammadiyah". Tujuan pendidikan yang didasari oleh keihlasan inilah yang kemudian menjadikan pendidikan Muhammadiyah sampai saat ini masih eksis bahkan berkembang dengan pesat. Secara garis besar, tujuan pendidikan Muhammadiyah lebih menekankan pada pembentukan moral dan al akhlak al karimah yang bersumber dari ajaran-ajaran Islam, tapi dalam praktiknya Muhammadiyah selalu mengadakan pembaharuan (tajdid) dan inovasi yang bersifat progresif dengan mengikuti perkembangan zaman.

Sebuah model lembaga pendidikan Islam modern yang diintrodusir Muhammadiyah pada akhir abad 20 adalah Hollandsch-Inlandsche School (HIS) met de Qur'an, yaitu sekolah pada zaman penjajahan Belanda yang pertama kali didirikan di Indonesia pada tahun 1914 seiring dengan diberlakukannya Politik Etis. Selanjutnya dikenal dengan "Sekolah Umum Plus" dan merupakan embrio daripada "Sekolah Islam Modern (Modern Islamic School)". HIS met de Qur'an 
mengintegrasikan sistem pendidikan Islam tradisional dengan sistem pendidikan barat modern. Di bawah naungan Muhammadiyah, konsep sekolah sekuler yang mengadopsi sistem kelembagaan barat modern ini ditambahkan di dalamnya mata pelajaran keagamaan sehingga ada integrasi yang kuat antara matakuliah umum dan matakuliah keagamaan. Muhammadiyah berusaha untuk menghilangkan dikotomi keilmuan antara ilmu umum dan agama. Bagi Muhammadiyah baik ilmu umum dan ilmu agama adalah satu kesatuan yang tidak boleh dipisahkan. Ilmu umum tanpa dilandasi ilmu agama akan sesat dan bisa mendatangkan kemadharatan bagi alam semesta, sedangkan ilmu agama yang tidak ditopang dengan ilmu pengetahuan umum lainnya maka akan pincang, tertinggal oleh arus kemajuan zaman. Mempelajari ayat-ayat qouliyah sangat penting, begitu pula mempelajari ayat-ayat kauniyah juga penting. Oleh sebab itu, keduanya harus samasama dipelajari untuk memperoleh ilmu pengetahuan yang utuh. Inilah model sekolah yang ditawarkan Muhammadiyah yang akhirnya menjadi alternatif bagi lembaga pendidikan yang ada. Selain itu, model sekolah ini juga berperan penting dalam rekonsiliasi antara cendekiawan barat dan intelektual Muslim.

Sebagai organisasi kemasyarakat yang menaruh perhatian di dunia pendidikan, maka Muhammadiyah dalam mendirikan pendidikan memiliki sebuah landasan tertentu. Landasan pendirian pendidikan Muhammadiyah adalah sebuah motivasi teologis yang menjelaskan bahwa untuk mencapai kesempurnaan dalam keimanan dan ketaqwaan, seorang manusia harus memiliki kedalaman ilmu pengetahuan. Al Qur'an menjelaskan bahwa seorang yang memiliki keimanan dan memiliki ilmu pengetahuan maka akan bermartabat, derajatnya akan diangkat oleh Allah Swt (al Mujadalah: 11). Untuk memperoleh ketaqwaan yang sempurna maka harus memahami agama dengan baik dan benar. Syarat untuk dapat memahami agama dengan baik dan benar harus melalui ilmu pengetahuan.

Sebuah ilmu pengetahuan dapat dipelajari dan diperoleh dengan baik melalui sebuah proses pendidikan yang baik pula. Maka sebagai manifestasi daripada motivasi teologis ini, KH. Ahmad Dahlan yang merupakan pendiri Muhammadiyah menyelenggarakan pendidikan agama sebagai bentuk amal sholeh. Selanjutnya, terjadilah pembaharuan pendidikan dikarenakan kondisi yang ada sehingga sistem pendidikan yang ada dibuat dengan cara memadukan atau integrasi antara ilmu agama dan ilmu umum dengan harapan untuk melahirkan seorang intelek yang ulama atau ulama yang intelek.

Jika dilihat dari aspek organisasi dan amal usaha, maka Muhammadiyah adalah organisasi Islam terbesar di dunia. Muhammadiyah adalah organisasi Islam dengan kelembagaan modern yang paling berjaya. Berbagai amal usaha yang dimilikinya termasuk didalamnya pendidikan menjadikannya semakin kokoh dan 
Berjaya. Nurcholis Majid pernah mengatakan bahwa Muhammadiyah adalah cerita kejayaan (Binfas et al., 2014). Sepak terjang Muhammadiyah dalam menghiasi dan mewarnai dunia pendidikan di Indonesia tidak diragukan lagi. Kejayaan Muhammadiyah dalam bidang pendidikan terbukti dengan jumlah lembaga pendidikan yang dimilikinya. Sebagaimana yang tertulis di Republika, pada tahun 2015 saja Muhammadiyah telah memiliki lembaga pendidikan tingkat TK/TPQ sebanyak 4.623, Sekolah Dasar (SD)/MI 2.604, Sekolah Menengah Pertama (SMP)/MTs 1.772, Sekolah Menengah Atas (SMA)/SMK/MA 1.143, Pondok Pesantren 67, Sekolah Luar Biasa (SLB) 71, dan Perguruan Tinggi Muhammadiyah sebanyak 172. Seluruh lembaga pendidikan yang dimiliki oleh Muhammadiyah ini tersebar diseluruh penjuru nusantara dari Sabang sampai Merauke, dari tanah rencong Aceh sampai tanah Papua.

Jika bertolak dari cakupan tujuan awal berdirinya Muhammadiyah yaitu menyebarkan ajaran Nabi Muhammad SAW di bumi Yogyakarta, maka cakupan itu telah terpenuhi, bahkan jauh terlewati. Lembaga pendidikan Muhammadiyah telah tersebar dihampir seluruh bumi nusantara ini, bahkan sampai daerah pelosok sekalipun. Pendidikan Muhammadiyah telah berkiprah secara nasional, bahan go internasional. Muhammadiyah kini telah menyiapkan untuk membangun perguruan tinggi Muhammadiyah di luar negeri.

Abdul Mu'ti (dalam prolog Mengokohkan Spirit Muhammadiyah) menyatakan bahwa Muhammadiyah adalah gerakan pembaharuan Islam yang bergerak dalam bidang pendidikan, kesehatan, ekonomi, dan pemberdayaan masyarakat. Muhammadiyah melakukan pembaharuan dalam bidang pendidikan melalui tiga hal, pertama dalam hal kurikulum. Pendidikan Muhammadiyah mengajarkan studi agama dan studi umum sekaligus. Ilmu agama diajarkan untuk memberikan pondasi keimanan dan keagamaan yang kokoh bagi anak didik agar tidak salah melangkah. Pembentukan akhlak dan moral adalah yang utama sehingga terinternalisasi dalam diri anak didik nilai-nilai Islam yang akhirnya tercermin dari prilaku sehari-hari. Begitu pula ilmu umum juga diajarkan untuk memberikan pengetahuan tentang keduniaan, pengetahuan tentang alam semesta, sehingga anak didik tidak ketinggalan oleh siswa lainnya dalam pengetahuan umum.

Kedua, pembaharuan metode. Pendidikan Muhammadiyah melakukan pembaharuan dari metode klasik ke metode modern (Yusra, 2018). Kemajuan dan perkembangan dunia pendidikan tak lepas daripada metode pembelajaran yang digunakan. Berbagai metode modern yang dianggap berhasil dalam proses pendidikan selayaknya diterapkan untuk memperoleh hasil yang maksimal dalam pendidikan. Sebaliknya, metode yang bersifat klasik yang sudah tidak relevan lagi harus mulai ditinggalkan. 
Ketiga pembaharuan institusional. Muhammadiyah membuat pembaharuan dengan memadukan sistem pendidikan sekolah dan pesantren atau yang dikenal dengan istilah boarding school. Beberapa lembaga pendidikan Muhammadiyah yang berbasis boarding school kini sudah banyak ditemui di beberapa tempat. Sistem boarding school yang dikembangkan Muhammadiyah ini bertujuan agar tercipta lingkungan yang intelektual agamis. Anak didik langsung dapat memperoleh dua keilmuan yaitu ilmu umum dan ilmu agama dalam satu tempat yang sama. Dinamika pembaharuan pendidikan Muhammadiyah ini akan terus berjalan seiring dengan perubahan zaman.

Berdasarkan Keputusan Muktamar Muhammadiyah Ke-46 tentang Revitalisasi Pendidikan Muhammadiyah yang termuat dalam Tanfidz Keputusan Muktamar Satu Abad Muhammadiyah, visi pendidikan Muhammadiyah adalah "Terbentuknya manusia pembelajar yang bertaqwa, berakhlak mulia, berkemajuan dan unggul dalam IPTEKS sebagai perwujudan tajdid dakwah amar ma'ruf nahi munkar (Muhammadiyah, 2010). Untuk mengimplementasikan visi tersebut maka ada enam nilai dasar yang dibangun dalam pendidikan Muhammadiyah. Pertama, dalam penyelenggaraan pendidikan Muhammadiyah harus merujuk pada nilai-nilai yang bersumber dari al-Qur'an dan as-Sunnah. Kedua, pelaksanaan pendidikan harus didasari oleh keikhlasan dan semata-mata mencari ridlo Allah Swt. Ketiga, ada kerjasama dengan pihak lain yang terlibat, dengan tetap bersikap kritis. Keempat, selalu memegang prinsip tajdid, dengan melakukan berbagai inovasi untuk menjalankan dan memajukan pendidikan. Kelima, berpihak kepada kaum yang lemah melalui tindakan kreatif untuk menjawab setiap tantangan yang berkembang di masyarakat. Keenam, selalu menjaga keseimbangan antara akal sehat dan kesucian hati dalam mengelola lembaga pendidikan (Suharto, 2015).

Meskipun secara eksistensi Muhammadiyah berada dibawah naungan NKRI, namun tidak setiap kebijakan perubahan terkait dengan pendidikan serta merta diikuti oleh Muhammadiyah. Muhammadiyah selalu berfikir kritis dalam menanggapi setiap kebijakan dan perubahan yang ada. Setiap kebijakan akan selalu dikaji mendalam dengan melihat berbagai sudut pandang yang ada, mempertimbangkan relevansi daripada implementasi setiap kebijakan, serta faktor terkait lainnya untuk memperoleh hasil terbaik.

Pendidikan Muhammadiyah terbilang kuat dan kokoh. Ini dibuktikan dengan eksistensi yang dimilikinya sampai saat ini. Keberadaan pendidikan Muhammadiyah yang mampu melewati berbagai lintasan zaman membuktikan bahwa pendidikan Muhammadiyah layak untuk dijadikan pedoman. Pendidikan Muhammadiyah mampu bertahan dengan segala lika-liku yang dihadapinya mulai dari zaman kolonial Belanda, penjajah Jepang, orde lama, orde baru, era reformasi 
bahkan pasca reformasi. Bagi pendidikan Muhammadiyah, setiap zaman yang dilewatinya memiliki variasi problematika, rintangan dan tantangan tersendiri, namun dengan gigihnya pendidikan Muhammadiyah mampu melewati itu semua. Padahal tidak sedikit lembaga pendidikan lainnya yang seusia dengan Muhammadiyah atau bahkan tergolong lebih muda harus gulung tikar karena tergulung ombak dan tergerus oleh keadaan.

\section{Peluang dan Tantangan Pendidikan Muhammadiyah}

Berbagai terobosan untuk menghadirkan peluang bagi sebuah lembaga pendidikan untuk terus eksis dan mendapatkan perhatian masyarakat terkait pendidikan terus dilakukan. Di antaranya terdapat beberapa lembaga pendidikan yang menghadirkan atau mengadopsi kurikulum dari luar negeri yang dianggapnya lebih efktif dan mengurangi beban siswa dalam belajar. Selain itu, juga beberapa lembaga pendidikan mengadopsi strategi, metode serta cara-cara baru yang dianggapnya relevan dan menarik bagi anak didik untuk diterapkan di sekolah dan lembaga pendidikan lainnya. Fasilitas pendidikan berupa gedung, peralatan belajar dan lain sebagainya juga tak luput dari perhatian. Semuanya disetting dibuat sedemikian rupa dengan harapan memberi harapan baru untuk tetap memberikan eksistensi sebuah lembaga pendidikan agar tidak ditinggalkan oleh peminatnya. Semua gerakan ini dilakukan oleh berbagai bentuk lembaga pendidikan. Tak terlepas di dalamnya lembaga pendidikan Muhammadiyah juga ikut andil agar pendidikan yang ada di dalamnya dapat terus bertahan dan mampu memberikan peluang untuk selalu diminati serta mampu menjawab berbagai tantangan dalam bidang pendidikan yang ada di depan.

Tidak dapat dipungkiri, saat ini umat Islam sangat berharap dan memerlukan lembaga pendidikan yang maju, inovatif yang unggul dalam kualitas. Jika harapan dan keinginan tersebut tidak terpenuhi maka fenomena larinya generasi muda muslim ke lembaga pendidikan non-Muslim yang dianggap lebih berkualitas masih akan terus terjadi. Pada akhirnya, umat Islam sendiri yang akan mengalami kerugian. Oleh sebab itu, sudah menjadi sebuah keharusan untuk dapat menghadirkan pendidikan Islam yang inovatif, kreatif, unggul dan berkualitas agar dapat sejalan dengan zaman yang ada dan mampu berkompetisi dengan lembaga pendidikan lainnya. Pendidikan yang ada hendaknya ditransformasikan untuk usaha membangun kekuatan dan kemandirian di bidang politik, ekonomi, sosial budaya secara terpadu demi kesejahteraan umat dengan tetap memegang teguh tujuan akhir pendidikan yaitu terbentuknya anak didik yang berakhlak al karimah, menjadi insan kamil yang dapat memberikan mafaat bagi kehidupan manusia serta 
alam disekitarnya sehingga dapat mewujudkan negara yang baldatun thoyyibatun wa rabbun ghofur.

Perkembangan pendidikan Muhammadiyah di Indonesia memiliki kemajuan yang sangat pesat. Gerakan tajdid dan reformis yang menjadi sistem pendidikan Muhammadiyah mendapat sambutan hangat dan positif dari berbagai pihak dan kalangan. Berbagai prestasi baik tingkat lokal, nasional maupun internasional pun telah diukir dan diraih oleh berbagai lembaga pendidikan Muhammadiyah sebagai buah dari hasil pendidikan yang diterapkan selama ini. Bahkan salah satu contohnya adalah baru-baru ini ada 13 siswa SD Muhammadiyah 4 Pucung Surabaya telah meraih prestasi dengan menjuarai lomba di beberapa cabang lomba tingkat internasional, di antaranya adalah 6 siswa meraih 4 silver medal, 1 bronze medal, dan 1 juara harapan ajang Thailand International Mathematic Olympiad (TIMO). Selain itu, juga ada 7 siswa yang meraih medali emas dan perak dalam kompetisi RoboCup Junior Rescue Line, Primary, RoboCup Singapore Open tahun 2019. Tentunya prestasi yang telah diraih ini sangat membanggakan khsususnya pada lembaga pendidikan Muhammadiyah tersendiri karena telah berhasil mengantarkan anak didiknya untuk berprestasi dalam kancah internasinal.

Muhammadiyah selalu berupaya untuk menciptakan dan membuka peluangpeluang bagi kemajuan lembaga pendidikan yang dimilikinya. Selain berupaya untuk selalu berprestasi, Muhammadiyah juga terus membangun dan menyebarluaskan lembaga pendidikannya di penjuru tanah air bahkan ke luar negeri. Peluang pendidikan Muhammadiyah untuk dapat mewarnai dunia pendidikan di tanah air dan dunia, serta untuk dapat dijadikan pelabuhan tempat menimba ilmu pengetahuan semakin terbuka dikarenakan beberapa hal, di antaranya. Pertama, pendidikan Muhammadiyah mengusung gerakan tajdid atau pembaharuan. Sistem Pendidikan Muhammadiyah tidak terkekang dengan konservatifme yang mempertahankan tradisi lama dan tidak mau berubah untuk menerima modernisasi. Pendidikan Muhammadiyah selalu berusaha membuat perubahan dan pembaharuan dengan modernisasi sistem pendidikan untuk lebih baik dan maju. Berbagai program dan gerakan inovatif diciptakan dan dilakukan untuk memajukan lembaga pendidikan yang ada. Muhammadiyah tidak kaku dalam setiap pembaharuan yang dibuatnya meskipun tetap mempertahankan prinsip dasar yang menjadi landasannya. Gerakan tajdid pendidikan Muhammadiyah ternyata banyak diterima oleh kalangan lain bahkan menginspirasi lembaga pendidikan lainnya sehingga pendidikan Muhammadiyah menyita perhatian dan memiliki tempat bagi lembaga-lembaga lainnya dikarenakan beberapa keberhasilan yang telah diraih. Bagi Muhammadiyah, pendidikan adalah suatu keniscayaan dan harus bersifat holistic yaitu menyeimbangkan antara pendidikan agama dan umum 
sebagaimana konsep awal pendidikan yang digagas oleh pendirinya. Maka Muhammadiyah menyelenggarakan pendidikan modern sesuai dengan tuntutan zaman (Mafidin, 2012). Sehingga harapan untuk melahirkan dan membentuk ulama yang intelek atau intelek yang ulama akan dapat terwujud.

Kedua, arah dakwah pendidikan Muhammadiyah sejalan dan searah dengan tujuan Indonesia merdeka, yaitu untuk mencerdaskan kehidupan bangsa sebagaimana yang termaktub dalam pembukaan UUD 1945. Perhatian pendidikan Muhammadiyah sangat menitikberatkan pada Sumber Daya Mamnusia (SDM) yang unggul dan berkualitas. Hal Ini selaras dengan apa yang dicita-citakan oleh Presiden Republik Indonesia Joko Widodo dalam visi misinya yang menekankan pada pembangunan sumber daya manusia. Hadirnya SDM yang unggul dan berkualitas akan membawa kemajuan besar bagi bangsa. Maka tidak heran jika tema milad Muhammadiyah yang ke 107 yang jatuh pada tanggal 18 November 2019 lalu mengusung tema "Mencerdaskan Kehidupan Bangsa" sebagai bentuk langka Muhammadiyah untuk bersungguh-sungguh membantu pemerintah dalam meningkatkan sumber daya manusia Indonesia. Peningkatan SDM dalam ilmu pengetahuan sangat perlu dilakukan, karena Indonesia yang sudah dikaruniai Sumber Daya Alam (SDA) yang melimpah. Jika tidak diimbangi dengan SDM yang baik, maka potensi alam yang ada akan sia-sia dan justru akan menjadi boomerang sendiri bagi bangsa ini. Di sinilah langkah pendidikan Muhammadiyah semakin mendapat sorotan dari semua pihak bahkan negara sendiri, dikarenakan banyak kesamaan tujuan yang diusung antara pemerintah dan Muhammadiyah. Pendidikan Muhammadiyah dianggap mampu memberikan spirit perjuangan pendidikan yang progresif untuk kemaslahatan umat.

Ketiga, pembaharuan kurikulum. Gerakan tajdid yang dilakukan oleh pendidikan Muhammadiyah dalam mengintegrasikan ilmu agama dan ilmu umum sebagaimana yang diusung oleh KH. Ahmad Dahlan sangat relevan dengan kondisi saat ini yang semuanya dituntut untuk melek dengan teknologi. Era disrupsi yang ada tidak mungkin dapat dihindari, tapi harus disambut dengan mempersiapkan diri secara matang. Semua pihak khususnya yang terkait dengan lembaga pendidikan tidak boleh gaptek. Pembaharuan kurikulum yang memadukan antara pendidikan agama dan pendidikan umum inilah yang menjadikan pendidikan Muhammadiyah sampai saat ini dapat eksis dan bertahan bahkan cenderung berkembang.

Keempat, kekuatan jaringan. Lembaga pendidikan Muhammadiyah memiliki jaringan yang kuat khususnya sesama lembaga pendidikan Muhammadiyah, juga dengan lembaga pendidikan lain baik tingkat nasional maupun internasional. Muhammadiyah telah mendapatkan banyak kepercayaan sehingga mudah diterima 
oleh pihak lain. Kekuatan jaringan pendidikan Muhammadiyah dikuatkan lagi dengan akan dibangunnya beberapa lembaga pendidikan di luar negeri.

Pada abad sekarang ini, pendidikan memiliki tantangan yang sangat besar. Perubahan untuk menerapkan pendidikan yang baik dan maju harus ada, agar tidak tertinggal dan tergerus oleh masa. Lembaga pendidikan harus menyediakan seorang pendidik yang kompeten dalam pendidikan. Seorang pendidik harus mampu improvisasi dalam mengajar, melek teknologi digital, serta kompetitif. Hal ini sebagaimana yang diungkapkan oleh pendiri Alibaba Group, Jack Ma pada acara tahunan World Economic Forum, bahwa jika seorang pendidik pada suatu lembaga pendidikan tidak merubah cara mendidik dan mengajarnya, maka 30 tahun mendatang akan mengalami kesulitan. Ini mengisyaratkan bahwa lembaga pendidikan harus mampu berkompetisi dengan baik, karena jika tidak mampu maka tidak akan ada yang minat, serta akan ditinggalkan oleh masyarakat. Pendidikan yang dihadirkan kepada peserta didik hendaknya memperhatikan aspek muatan sikap dan keterampilan agar dapat terimplementasikan oleh peserta didik sehingga mereka mampu berkompetisi dengan baik.

Peluang yang dimiliki oleh pendidikan Muhammadiyah tentunya harus dipelihara dan ditingkatkan terus. Pendidikan Muhammadiyah tidak boleh terbius dan terlena dengan keberhasilannya alam membangun lembaga pendidikan yang ada. Kuantitas lembaga pendidikan yang ada seharusnya diimbangi dengan kualitas. Apalagi di era 4.0 berbagai tantangan yang ada di depan harus siap untuk dihadapi. Era 4.0 yang merupakan era digitalisasi pendidikan merupakan tantangan berat bagi pendidikan Muhammadiyah. Berbagai tantangan yang dihadapi oleh dunia pendidikan pada era 4.0 di antaranya: pertama, secara global era digitaliasi akan menghilangkan 1 sampai 1,5 milyar pekerjaan sepanjang tahun 2015 sampai tahun 2025. Posisi manusia akan digantikan oleh mesin otomatis atau teknologi mesin. Kedua, adanya prediksi bahwa 65 persen murid sekolah dasar di dunia akan mengerjakan suatu pekerjaan yang belum ada saat sekarang ini.

Berbagai tantangan terkait pendidikan dihadapi oleh Muhammadiyah. Tantangan tersebut di antaranya terkait dengan kuantitas lembaga Muhammadiyah yang maju pesat, akan tetapi tidak diimbangi dengan kualitas pendidikan yang ada. Menjamurnya sekolah-sekolah dan universitas Muhammadiyah di tanah air yang tidak diikuti oleh peningkatan kualitas kurang memberikan sumbangsih bagi bangsa. Kendati ada beberapa peningkatan kualitas dan mutu pendidikan di beberapa lembaga pendidikan yang dimiliki oleh Muhammadiyah, namun pada kenyataannya perubahan itu belum merata sehingga pendidikan Muhammadiyah terkesan stagnan. Inovasi dan improvisasi di bidang pendidikan juga belum banyak didapatkan. Pendidikan Muhammadiyah secara umum juga terkesan belum mampu 
bersaing secara nasional apalagi internasional. Tantangan lain yang dihadapi pendidikan Muhammadiyah adalah pada kompetensi guru. Masih banyak guru di lembaga pendidikan Muhammadiyah yang masih gaptek. Selain itu, metode pengajaran dan fasilitas pendidikan di sekolah juga menjadi sorotan tersendiri yang harus dibenahi oleh lembaga pendidikan Muhammadiyah.

Tantangan berat yang dihadapi lembaga pendidikan Muhammadiyah yang tak kalah penting adalah pembelajaran mata pelajaran Al Islam dan Kemuhammadiyahan (AIK) yang menjadi ciri khusus dari lembaga Muhammadiyah. Dua mata pelajaran ini merupakan ruh bagi Muhammadiyah yang sangat vital, sehingga mata pelajaran tersebut harus diajarkan dan ditanamkan kepada para anak didik di lembaga Muhammadiyah dari tingkat dasar sampai perguruan tinggi (Arifin, 2015). Mata pelajaran ini bertujuan memberikan dasar dan pondasi akan pemahaman Islam dan juga tentang Muhammadiyah. Tapi realita yang ada di lapangan justru ditemukan, bahwa pelajaran yang seharusnya memiliki prioritas khusus sebagai benteng moral dan ideologi anak didik ini seringkali diajarkan hanya sebatas formalitas (Nuryana, 2017). Oleh sebab itu, revitalisasi AIK di semua tingkat pendidikan Muhammadiyah adalah sebuah urgensitas yang harus segera diimplementasikan.

Menyikapi setiap tantangan yang ada, maka perlu bagi pendidikan Muhammadiyah untuk menjawab setiap tantangan yang ada dengan langkahlangkah dan progressive programs. Pendidikan Muhammadiyah harus mampu menerapkan strategi untuk merespon setiap peluang dan tantangan pendidikan yang ada di era industri 4.0. Di antara langkah strategi yang diambil adalah dengan terus berkomitmen untuk meningkatkan investasi dalam pengembangan kemampuan digital (digital skills), mengaplikasikan prototype teknologi terbaru melalui metode learning by doing secara kontinuitas, berkolaborasi baru dalam pendidikan untuk peningkatan kemampuan digital dengan dunia pendidikan, dunia usaha dunia industri, melakukan pengembangan kurikulum dengan memasukkan materi human digital skills. Sebagai gerakan dakwah dan tajdid di bidang pendidikan, Muhammadiyah harus melakukan revitalisasi intelektualitas untuk meningkatkan kualitas pengetahuan, wawasan dan pemikiran yang juga merupakan semangat Islam. Selain itu, sebagaimana yang termaktub dalam tanfidz Muhammadiyah, bahwa pendidikan Muhammadiyah telah membuat rencana strategis untuk peningkatan SDM, IPTEK, serta eksplorasi aspek-aspek kehidupan bercirikan Islam untuk kemajuan dan keunggulan di tingkat nasional maupun regional (Muhammadiyah, 2010). Semuanya dilakukan dengan membuat peta konsep atau roadmap pengembangan IPTEK Muhammadiyah, menggalakkan penelitian-penelitian dan membangun jaringan kerjasama dengan lembaga 
penelitian yang ada, serta menjadikan mutu pendidikan sebagai tujuan utama pendidikan.

Sebagai bentuk implementasi strategi di atas maka Muhammadiyah telah meluncurkan program Muhammadiyah Online University (MOU), tepatnya pada saat milad Muhammadiyah ke 107 tanggal 18 November 2019 lalu di gedung Sportorium Universitas Muhammadiyah Yogyakarta. Adapun untuk program studi yang menjadi cikal bakal daripada penerapan MOU ini adalah Manajemen, Teknik Informatika, dan Kesehatan Masyarakat. Menurut ketua umum Muhammadiyah Haedar Nashir, MOU ini disiapkan sebagai satu sistem tersendiri yang dapat mencakup seluruh kampus Muhammadiyah di Indonesia dengan basis kuliah online. Ini juga sebagai bentuk pengembangan perkuliahan yang dapat dilakukan secara online tanpa harus pergi ke kampus.

Dalam menghadapi era industri 4.0 Muhammadiyah tengah melakukan akselerasi dan ekspansi untuk memajukan lembaga pendidikan Muhammadiyah dari tingkat dasar sampai perguruan tinggi. Selain itu, lembaga pendidikan Muhammadiyah juga memperkokoh jaringannya dengan lembaga pendidikan lainnya. Menurut Haedar Nashir (Pimpinan Pusat Muhammadiyah), melalui proses akselerasi dan ekspansi diharapkan lembaga pendidikan Muhammadiyah mampu bersaing di era revolusi industri 4.0 dan dapat meningkatkan akreditasi lembaga pendidikan. Haedar menambahkan bahwa dalam menghadapi tantangan di era 4.0 ini kualitas lembaga pendidikan juga perlu ditingkatkan. Kita harus menjadi umat yang unggul dan berkualitas, sedikit bicara banyak aksi. Dalam waktu dekat Muhammadiyah juga akan membangun Universitas Muhammadiyah di Australia dengan harapan dapat mempermudah akses pendidikan bagi warga Indonesia yang tinggal di Australia, tapi juga tidak menutup kemungkinan akan terbuka untuk umum.

\section{Simpulan}

Muhammadiyah adalah organisasi Islam besar yang menjadikan pendidikan sebagai sarana dakwah perjuangnnya. Secara umum, tujuan pendidikan Muhammadiyah adalah membentuk manusia muslim yang berakhlak mulia, berbudi pekerti luhur, mengembangkan ilmu pengetahuan dan keterampilan demi terwujudnya masyarakat yang adil dan makmur yang diridhoi Allah Swt. Pendidikan Muhammadiyah memiliki ciri khas mata pelajaran yang harus dipelajari semua lembaga pendidikan Muhammadiyah yaitu keislaman dan kemuhammadiyahan.

Dalam memasuki era industri 4.0 pendidikan Muhammadiyah menghadapi berbagai peluang dan tantangan. Muhammadiyah selalu berusaha untuk menjawab setiap peluang dan tantangan yang ada dengan selalu meningkatkan kualitas dan 
mutu pendidikan, membuat jaringan yang kuat antar lembaga pendidikan serta melakukan ekspansi lembaga pendidikan baik di dalam negeri maupun luar negeri. Muhammadiyah juga berusaha membuat terobosan-terobosan baru pada ranah pendidikan dengan membuat program berbasis teknologi sebagai bentuk kesiapan dalam menyambut era disrupsi dengan membangun program pembelajaran dan perkuliahan berbasis teknologi.

\section{Daftar Rujukan}

Ali, M. (2016). MEMBEDAH TUJUAN PENDIDIKAN MUHAMMADIYAH. Profetika: Jurnal Studi Islam. https://doi.org/10.23917/profetika.v17i01.2099.

Ali, M., \& Ali, M. (2004). FILSAFAT PENDIDIKAN MUHAMMADIYAH:Tinjauan Historis dan Praksis. Tajdida: Jurnal Pemikiran Dan Gerakan Muhammadiyah, 2(2), 123-140. https://publikasiilmiah.ums.ac.id/xmlui/handle/11617/1051.

Ali, M., Kuntoro, S. A., \& Sutrisno, S. (2016). Pendidikan Berkemajuan: Refleksi Praksis Pendidikan K.H. Ahmad Dahlan. Jurnal Pembangunan Pendidikan: Fondasi Dan Aplikasi, 4(1), 43. https://doi.org/10.21831/jppfa.v4i1.7821.

Arifin, S. (2015). Rekonstruksi Al-Islam-Kemuhammadiyahan Praksis Pendidikan Nilai Reconstruction of Al-Islam- Kemuhammadiyahan ( Aik ) in Muhammadiyah Universities As the Praxis of Value Education. Jurnal Al-Islam Dan Kemuhammadiyahan.

Arofah, S., \& Jamu'in, M. (2015). Gagasan Dasar dan Pemikiran Pendidikan Pendidikan Islam K.H Ahmad Dahlan. Tajdida, 13(2), 114-124.

Binfas, M. A. M., Abdullah, M. S. Y., \& Ismail, A. M. (2014). Asal usul gerakan pendidikan Muhammadiyah di Indonesia. Asal Usul Gerakan Pendidikan Muhammadiyah Di Indonesia., 7756, 66-80.

Listiana, H. (2015). LEMBAGA PENDIDIKAN ISLAM AKHIR ABAD XX Studi Pendidikan Muhammadiyah Sekolah Umum Plus dan Boarding School. TADRIS: Jurnal Pendidikan Islam, 10(2), 230. https://doi.org/10.19105/tjpi.v10i2.827.

Mafidin. (2012). STUDI LITERATUR TENTANG PERAN MUHAMMADIYAH DALAM MENGEMBANGKAN PENDIDIKAN ISLAM DI INDONESIA Oleh: Mafidin. Jurnal Tarbawi, 1(1), 43-53. http://jurnal.upi.edu/file/05_Studi_Literatur_Tentang_Peran_Muhammadiyah_Dal am_Mengembangkan_Pendidikan_Islam_Di_Indonesia_-_Mapidin.pdf. 
Muhammadiyah, P. P. (2010). Tanfidz Keputusan Muktamar Satu Abad Muhammadiyah. September, 1-148.

Nuryana, Zalik. (2017). REVITALISASI PENDIDIKAN AL ISLAM DAN KEMUHAMMADIYAHAN PADA PERGURUAN MUHAMMADIYAH. TAMADDUN.

Rusydi, R. (2017). PERAN MUHAMMADIYAH ( KONSEP PENDIDIKAN, USAHAUSAHA DI BIDANG PENDIDIKAN, DAN TOKOH). TARBAWI: Jurnal Pendidikan Agama Islam. https://doi.org/10.26618/jtw.v1i2.367.

Suharto, T. (2015). Gagasan Pendidikan Muhammadiyah dan NU sebagai Potret Pendidikan Islam Moderat di Indonesia. ISLAMICA: Jurnal Studi Keislaman. https://doi.org/10.15642/islamica.2014.9.1.81-109.

Wuryandani, W., Fathurrohman, F., \& Ambarwati, U. (2016). IMPLEMENTASI PENDIDIKAN KARAKTER KEMANDIRIAN DI MUHAMMADIYAH BOARDING SCHOOL. Jurnal Cakrawala Pendidikan. https://doi.org/10.21831/cp.v15i2.9882.

Yusra, N. (2018). Muhammadiyah: Gerakan Pembaharuan Pendidikan Islam. $\begin{array}{lllll}\text { POTENSIA: Jurnal Kependidikan } & \end{array}$ https://doi.org/10.24014/potensia.v4i1.5269. 